Katarzyna Białożyt

Uniwersytet Pedagogiczny im. Komisji Edukacji Narodowej w Krakowie

Katarzyna Zielińska-Król

Katolicki Uniwersytet Lubelski Jana Pawła II

\title{
Wyzwania i trudności w realizacji zasad etycznych w pracy socjalnej z osobami starszymi i z niepełnosprawnością
}

\section{The challenges and difficulties in the implementation of ethical principles in social work with the elderly and disabled}

The subject of the article discusses the issues associated with the ethical dimension of social work with the older person and disabled. The increasing number of older people with a disability generates new challenges and difficulties in the area of social services, especially social work. The article presents the most important ethical principles which should be followed in social work, and identified and discussed national and international documents which are the base of the standards and ethical principles.

Słowa kluczowe: zasady etyczne, praca socjalna, starość, niepełnosprawność

Keywords: ethic rules, social work, old age, disability

\section{Osoba starsza i osoba z niepełnosprawnością}

Wchodzenie $\mathrm{w}$ okres starości oraz doświadczanie niepełnosprawności są zupełnie innymi kategoriami doświadczeń i przeżyć, choć często doświadczenie starości i niepełnosprawności stawiane jest na równi. Złożona historia ideologii kulturowej, sił społecznych i gospodarczych oraz interwencji polityki społecznej konstruuje dwie odrębne sfery: wieku i niepełnosprawności. Dzieje się tak pomimo pozornych i intuicyjnych podobieństw co do warunków lub okoliczności funkcjonowania osób z niepełnosprawnością i osób starszych. Wiele z różnic zależy w dużym stopniu od poglądów i wyobrażeń co do ludzkich możliwości, a szcze- 
gólnie zaangażowania $\mathrm{w}$ pracę zarobkową, niezależnie od wieku nabycia niepełnej sprawności.

\section{Starość i niepełnosprawność. Razem czy oddzielnie. Wyjaśnienie stanowiska}

Sięgając do korzeni społeczeństwa industrialnego, produktywny wkład pracy, społeczny lub gospodarczy udział w życiu wspólnoty, był i nadal jest cechą wartości jednostki. Dorośli niezdolni do pracy z powodu złego stanu zdrowia lub ograniczonej zdolności funkcjonowania, którzy byli bez innych środków wsparcia materialnego, byli często spychani, marginalizowani, konsekwentnie pozbawiani możliwości angażowania się w życie społeczne i zawodowe. Osoby takie zazwyczaj zajmują stanowiska społeczne i zawodowe o stosunkowo niskiej wartości społecznej i materialnej. Choć wiek XXI przynosi znaczące zmiany w zakresie praw i inkluzji społecznej osób z niepełnosprawnością i starszych, to nadal dysproporcje między możliwościami, dostępem do dóbr (w tym edukacja i praca) oraz wynagrodzeniem za pracę jest wysoce nieadekwatne do wkładu pracy i zaangażowania. W okresie industrializacji osoby z niepełnosprawnością w każdym wieku nadal obejmowały marginesy płatnej siły roboczej. Dodatkowo sytuację osób starszych, jak i niepełnosprawnych pogarszał negatywny wizerunek obu grup, postrzeganych przez pryzmat możliwości dbania o XX wygenerował silny impuls w kierunku tworzenia polityki społecznej, której celem było rozwiązanie problemów pracy, ale przede wszystkim ubóstwa wśród osób starszych i z niepełnosprawnością. Do tego czasu korzyści społeczne w odniesieniu do zaawansowanego wieku lub niepełnosprawności były dość marginalizowane.

W późnych latach 60 . i na początku lat 70 . XX w. sieć usług dla osób z niepełnosprawnością i osób starszych stawała się coraz bardziej sformalizowana $\mathrm{w}$ większości krajów rozwiniętych lub rozwijających się. W tym okresie synergia ruchów na rzecz praw obywatelskich, zwiększenia liczby osób niepełnosprawnych podejmujących edukację i coraz bardziej znacząca liczba osób (także z niepełnosprawnością) działających na rzecz integracji i włączenia w życie społeczne, ekonomiczne oraz polityczne osób z niepełnosprawnością, doprowadziła do aktywnych i skutecznych działań zmierzających do przyznania pełnych praw obywatelskich dla osób z niepełnosprawnością, w tym dostęp do możliwości zasobów społecznych, gospodarczych i politycznych oraz włączenie do głównego nurtu społeczeństwa (Hahn 1994, s. 3-24).

W roku 1980 Światowa Organizacja Zdrowia (WHO) opracowała klasyfikację niepełnosprawności stanowiącą międzynarodowy wzorzec określania różnych możliwych konsekwencji wrodzonych lub nabytych deficytów zdrowotnych. 
Istotne jest rozgraniczenie, czy dana niepełnosprawność jest uszkodzeniem $\mathrm{w}$ sensie medycznym czy niezdolnością do wykonywania funkcji życiowych, czy tez upośledzeniem w sensie socjalnym. W zdecydowanej większości odchyleń od normy można wyróżnić za WHO trzy wymiary:

- uszkodzenie (impairment) oznaczające utratę lub nieprawidłowość struktury lub funkcji psychicznej, fizjologicznej lub anatomicznej;

- niepełnosprawność biologiczna (disability) oznaczająca wszelkie ograniczenia lub braki (wynikające z uszkodzenia) możliwości wykonywania pewnych czynności w sposób normalny w zakresie uznanym na takowy dla osób pełnosprawnych;

- upośledzenie lub niepełnosprawność społeczna (handicap) oznacza mniej korzystną sytuację danej osoby, wynikającej z uszkodzenia lub niepełnej sprawności, która uniemożliwia lub ograniczenia jej pełnienie ról wynikających z wieku, płci oraz sytuacji społecznej i kulturowej (Majewski 1995, s. 19).

Pierwowzorem tego ujęcia była koncepcja niepełnosprawności opracowana przez S. Nagiego, opublikowana w 1969 roku i - jak podaje Kirenko - do dnia dzisiejszego należąca do najczęściej cytowanych. Zgodnie z nią niepełnosprawność jest dynamicznym procesem złożonym z: patologii, uszkodzenia, ograniczenia funkcjonowania oraz niesprawności (Kirenko 2006, s. 14).

\section{Społeczny model niepełnosprawności}

W związku z wieloma zastrzeżeniami, jakie odnosiły się do zbyt dużego eksponowania aspektu medycznego i innych nieścisłości definicyjnych, WHO dokonała rewizji pojęcia niepełnosprawności funkcjonującej od 1980 roku: International Classification of Impairments, Disabilities and Handicaps, wprowadzając projekt International Classification of Impairments, Activities and Participation. Projekt ten przyjęty w 2000 roku zakłada przyjęcie całościowego, społecznego modelu niepełnosprawności:

- uszkodzenie (impairment) - dotyczy organizmu, jego funkcjonowania i budowy (w przypadku uszkodzenia organizm jednostki nie funkcjonuje prawidłowo);

- aktywność (activity) - dotyczy poziomu funkcjonowania jednostki, jej aktywności i działań (gdy organizm jest uszkodzony, jednostka doświadcza ograniczenia w swej aktywności);

- uczestnictwo (participation) - dotyczy relacji ze społeczeństwem i udziału jednostki w życiu społecznym (uszkodzenie i/lub ograniczenie aktywności powoduje, że jednostka napotyka bariery w społeczeństwie, jej uczestnictwo jest utrudnione). 
Nowa wersja klasyfikacji zachowuje dotychczasowe trzy wymiary niepełnosprawności, nadając im jednak trochę inny zakres znaczeniowy.

Działania te doprowadziły do wypracowania modelu społecznego niepełnosprawności, który był zbudowany na dotychczas funkcjonującym modelu medycznym. Model ten podlegał narastającej fali krytyki ze strony badaczy społecznych, aktywistów organizacji działających na rzecz niepełnosprawnych i polityków społecznych z powodu skutków, jakie przynosiło jego stosowanie dla położenia społecznego osób z niepełnosprawnością. Najkrócej rzecz ujmując, podsumować je można następującymi określeniami: wykluczenie społeczne, trwałe ubóstwo, uzależnienie ekonomiczne od pomocy instytucjonalnej. Rosnące rozmiary populacji osób z niepełnosprawnością, a także wzrastająca świadomość konsekwencji, jakie wywołuje przyrost liczby osób z niepełnosprawnością i starzejące się społeczeństwo dla poszczególnych jednostek oraz grup społecznych czy społeczeństwa jako całości, sprawia, że niepełnosprawność i starość traktowana jest coraz powszechniej jako istotne zagadnienie społeczne i ekonomiczne, a nie tylko zdrowotne lub medyczne.

To nie indywidualne ograniczenia są przyczyną niepełnosprawności, jak również nie sam wiek jest przyczyną wycofania z powodu starości, ale niedostarczanie przez społeczeństwo odpowiednich usług oraz brak właściwego zaspokojenia potrzeb osób z niepełnosprawnością i starszych, które nie są dostatecznie brane pod uwagę w organizacji życia społecznego (Kirenko 2007, s. 47).

W modelu społecznym niepełnosprawności uwaga skoncentrowana jest na społeczeństwie, jego organizacji oraz na określeniu położenia i statusu społecznego osób z niepełnosprawnością w zbiorowości. Pomimo że niepełnosprawność jest kategoryzowana jako odmienność, to w modelu społecznym zwraca się uwagę na rehabilitację całej społeczności (świadomość społeczna, postawy). Podkreślana jest również konieczność zmian w organizacji życia społecznego, ze szczególnym wskazaniem na integracyjny styl współżycia. Zatem z perspektywy społecznego modelu niepełnosprawności i barier, jakie piętrzą się w codziennym funkcjonowaniu, można przyjąć, że człowiek z niepełnosprawnością jest na tyle niepełnosprawny, na ile (Woźniak 2007, s. 37):

1. oczekuje tego społeczeństwo (normy, wzory, wartości, postawy),

2. organizacja społeczności i społeczeństwa globalnego umożliwia mu dostęp do głównego nurtu życia zbiorowego i zasobów.

Literatura przedmiotu dostarcza wielu katalogów głównych barier, na jakie napotyka osoba $\mathrm{z}$ niepełnosprawnością $\mathrm{w}$ codziennym życiu, $\mathrm{w}$ otoczeniu społecznym, we własnej przestrzeni. Za Michaelem P. Kelly oraz Davidem Lockerem najczęstsze bariery występują w: 
- samej osobie z niepełnosprawnością - jej poziom akceptacji własnej osoby, sytuacji, kondycji zdrowotnej, możliwości, kontroli nad własnym życiem, radzeniem sobie z trudnościami, poczucie bezradności;

- kulturze społeczeństwa globalnego i lokalnego przejawiające się w postawach społecznych, istniejących stereotypach, naznaczeniu społecznym wyrażanym w używanym języku, poziomie integracji społecznej oraz izolacji;

- rozwiązaniach organizacyjno-prawnych - dostęp do edukacji, rynku pracy, polityka zatrudnienia, opieka medyczna, wsparcie instytucjonalne, poradnictwo, zabezpieczenie prawno-materialne;

- organizacji i funkcjonowaniu systemu opieki medycznej oraz wsparciu społecznym;

- sposobie zagospodarowania przestrzeni i środowiska fizycznego, pokonywaniu barier architektonicznych, w przestrzeni publicznej, dostępności budynków użyteczności publicznej i mieszkalnych oraz komunikacji i transportu (Kelly, Locker 1996, s. 241-257).

Podczas gdy osoba i środowisko są dobrze dopasowane, niepełnosprawność i starość przestaje mieć aż tak duże znaczenie. Korzystanie z tej ramy czy też takiego rozumienia niepełnej sprawności, niezależne życie jest definiowane jako stan, w którym osoba jest w stanie osiągać swoje codzienne cele. Pełne obywatelstwo oznacza prawo do życia w społeczności, w których fizyczne, społeczne i kulturowe bariery uczestnictwa $\mathrm{w}$ społeczności i zaangażowania obywatelskiego na rzecz osób niepełnosprawnych nie są bardziej uciążliwe niż te dla osób pełnosprawnych.

Marginalizacja i brak autentycznego głosu osób niepełnosprawnych i starszych w dyskusji nad ich własnym życiem były kluczowymi czynnikami przyczyniającymi się do ponownych rozważań nad tym zagadnieniem. Niepełnosprawność nabyta po raz pierwszy w starszym wieku kształtuje ten stan, który dla wielu jest tożsamy. Starość bowiem postrzegana jest przez pryzmat niepełnej sprawności zarówno pod względem fizycznym, ruchowym, jak i psychicznym, charakterystycznym dla tego etapu życia. W fizjologicznej optyce nie ma podobieństw $\mathrm{w}$ doświadczeniu niepełnosprawności i starości, ale z perspektywy socjologicznej wiele czynników: począwszy od dyskryminujących postaw i zachowań, które ograniczają dostęp do edukacji, interakcji społecznych, zatrudnienia i życia rodzinnego aż do marginalizacji gospodarczej ze względu na wysokie koszty opieki zdrowotnej, ograniczonych możliwości zatrudnienia i kariery, wpływają na znaczące podobieństwo obu stanów (Putnam 2006, s. 11). Te różnice w doświadczeniu niepełnosprawności i starości są także różne ze względu na wiek.

Życie i prawa osób z niepełnosprawnością i starzejących się nadal postrzegane są jako oddzielne zagadnienia, choć - jak wskazano powyżej - z socjologicznego punktu widzenia obie rzeczywistości są dalece podobne. Starość i niepełnospraw- 
ność są powszechnie identyfikowane jako stany o zwiększonej potrzebie wparcia, inwestycji społecznych, także jako stan zmniejszający możliwości zatrudnienia, zarobkowania i integracji społecznej.

\section{Starość z niepełnosprawnością - trend nowoczesności}

Postępy w dziedzinie nauk medycznych, zdrowia publicznego i polityki społecznej w ciągu ostatniego stulecia przyczyniły się do powstania większej dostępności i wsparcia w kierunku osób niepełnosprawnych. To przyczyniło się do niedawno zidentyfikowanego w nauce i polityce społecznej zjawiska starzenia się z niepełnosprawnością. ",Starzenie się z niepełnosprawnością" odnosi się do sytuacji osób, którzy urodzili się lub nabyli/nabywają zaburzenia rozwojowe lub znaczne ubytki fizyczne na początku lub w połowie życia aż do późnej starości. Choć niepełnosprawność nieodparcie kojarzy się z wózkiem inwalidzkim, psem przewodnikiem czy sztuczną nogą, to tak naprawdę osoba z niepełnosprawnością jest postrzegana jako "nie w pełni” osoba. Jeśli nie tyle w odniesieniu do własnego funkcjonowania, satysfakcji z życia, możliwości, to także w kontekście życia dla społeczeństwa. Dotychczas najczęstszym przymiotnikiem jaki można spotkać w różnorakich badaniach nad postrzeganiem osób z niepełnosprawnością jest „zależny".

W języku angielskim funkcjonuje bardzo praktyczne rozróżnienie miedzy disabled (niepełnosprawność biologiczna) a handicapted (niepełnosprawność społeczna), które podkreśla subtelną różnicę w rozumieniu niepełnosprawności. Ten drugi rodzaj odnosi się do „niemożności” wypełniania wszystkich ról społecznych czy też aktywnego udziału w życiu społecznym, co jest bardzo typowe dla osób starszych. Zatem dookreślenie osoby starszej w kategoriach niepełnosprawnej nie powinno być odbierane jako zniewaga. Intencją jest raczej organizacja właściwej pomocy, wsparcia i rozumienia rzeczywistości osób starszych. Choć $\mathrm{w}$ wielu przypadkach takie ujęcie odzwierciedla funkcjonujący stereotyp, że każda osoba starsza jest osobą niesprawną w kontekście społecznym. Jest to dalekie od prawdy, choć w wielu przypadkach starość wpływa na zmniejszoną lub bardzo ograniczoną aktywność społeczną. Należy także podkreślić, że wiele osób starszych jest także niepełnosprawnych biologicznie (fizycznie i intelektualnie), co bywa konsekwencją deficytów z lat wcześniejszych lub też będących następstwem pogorszenia się stanu zdrowia i sprawności w wyniku wieku.

Wiek XX stał się świadkiem „epidemiologicznego przejścia” (epidemilogical transation), które wpłynęło na wydłużenie życia człowieka. Współczesny człowiek ma szansę żyć dłużej, a opieka i możliwości medyczne są na wysokim poziomie 
(Kunkel, Brown, Whittington 2014, s. 111). Jednak owa długość życia nie wpływa na jego sprawność. Zatem znak równości między zaawansowanym wiekiem człowieka a niepełną sprawnością (handicap) lub niepełnosprawnością (disability) jest bardzo zasadny, choć nie do każdego się odnoszący. Chociaż statystyki dotyczące populacji dorosłych w średnim wieku i starszych, których ten trend dotyczy, są ograniczone, szacuje się, że istnieje kilka milionów osób, które obecnie składają się na populację „starzejących się z niepełnosprawnością" i uważa się, że liczba ta stale wzrasta (Torres-Gil, Putnam 2004, s. 262-279). Populacja osób starzejących się wzrasta dwa razy szybciej niż populacja ludzi w ogóle. Ponad 1,2 mln osób wkracza miesięcznie w wiek starczy (Kunkel, Brown, Whittington 2014, s. 1). Warto zauważyć, że ten trend wzrostowy ma miejsce w tym samym czasie, kiedy liczba osób z niepełnosprawnością jest statystycznie coraz mniejsza w wieku do 65 roku życia, natomiast jest coraz większa w grupie osób powyżej 80 . roku życia (Crimmins 2004, s. 79-98). Dodając do tego także fakt wzrostu populacji osób starszych w ogóle, byłoby rozsąanie spojrzeć na nowe zjawisko jako rzeczywistość, która w coraz większym wymiarze będzie znajdowała swoje odzwierciedlenie nie tylko $\mathrm{w}$ statystykach polskich, ale także globalnych. Zatem można przypuszczać, że doświadczenie niepełnosprawności w starości stanie się nie tyle tendencją, co zupełnie znaczącą, heterogeniczną populacją osób starszych.

Jednak, co warto zauważyć, starzenie się z niepełnosprawnością jest zjawiskiem, którym nie zajęto się dotychczas wystarczająco ani w dziedzinie nauk gerontologii, ani socjologii czy polityki społecznej. Zatem brakuje odpowiedniego zrozumienia tego, w jaki sposób doświadczenie życia z przewlekłą niepełnosprawnością wpływa na doświadczenie starzenia się. Dodatkowo rodzi się nowe pytanie na temat przyszłego kierunku badań i praktyki w zakresie tych badań oraz praktyki pracy z osobami tworzącymi grupę osób starzejących się z niepełnosprawnością. Chociaż nie istnieją jasne prognozy co do długości życia osób starzejących się ze znacznymi niepełnosprawnościami, istnieją pewne dowody na to, że długość ta różni się od długości życia osób z niepełnosprawnością nie starzejących się, i że różnice te są istotne. Medycyna dopiero zaczyna rozumieć biologię i fizjologię starzenia się z niepełnosprawnością. Wiedza w ramach dziedzin nauk społecznych jest równie ograniczona. Mamy wiele do zrobienia, aby zrozumieć i poznać starzenie się z niepełnosprawnością, wprowadzić praktykę w zakresie tendencji w zakresie badań, praktyki zawodowej i budowania wiedzy społecznej. Jest prawdą, że starzenie z niepełnosprawnością jest wyraźną tendencją, a osoby żyjące w tej rzeczywistości napotykają na realne problemy, te jednak są dotychczas zbyt mało poznane przez specjalistów, którzy doświadczają wielu trudności w rozwiązywaniu potrzeb osób dotkniętych zarówno starością, jak i niepełnosprawnością. 


\section{Źródła zasad etycznych w pracy pracownika socjalnego $\mathrm{w}$ odniesieniu do pracy z osobami starszymi i z niepełnosprawnością}

W odniesieniu do polskich przepisów regulujących zatrudnienie na stanowisku pracownika socjalnego [Ustawa z dnia 12 marca 2004 r. o pomocy społecznej (tekst jedn.: Dz. U. z 2009 r. Nr 175, poz. 1362, z późn. zm.; Ustawa z dnia 16 lutego 2007 r. o zmianie ustawy o pomocy społecznej (Dz. U. Nr 48, poz. 320)] odpowiednie ustawy przewidują, że pracownikiem socjalnym może być osoba, która ma odpowiednie kwalifikacje zawodowe, tzn. ukończyła szkołę pracowników socjalnych lub studia wyższe o kierunku: praca socjalna, polityka społeczna, resocjalizacja, socjologia, pedagogika, psychologia lub inne pokrewne. Pracownikiem socjalnym może być również osoba z wyższym wykształceniem o kierunku nie wymienionym powyżej, jeśli ukończyła specjalizację z zakresu pomocy społecznej.

Pracownika socjalnego w Polsce obowiązują standardy etyczne określone w Kodeksie Etycznym Pracowników Socjalnych (KEPS), Polskiego Towarzystwa Pracowników Socjalnych (PTPS). Jednak podkreślić należy, że wspomniany kodeks jest dokumentem utworzonym na podstawie wielu innych aktów, które w swojej treści podkreślają podstawowe wartości w odniesieniu do pracy z osobą. W artykule autorzy dokonają analizy tych dokumentów, które wydają się najważniejsze w odniesieniu do pracy socjalnej, ze szczególnym uwzględnieniem zapisów odnoszących się do osób starszych oraz z niepełnosprawnością.

Konstytucja Rzeczpospolitej Polskiej

Najważniejszym i pierwszych aktem odnoszącym się do relacji z człowiekiem jest Konstytucja RP. Choć, w sposób oczywisty, nie odnosi się wprost do pracy socjalnej z osobą, to jednak jako akt najwyższej rangi podkreśla te wartości, które dla każdego człowieka są najistotniejsze. Rozdział II Konstytucji (Konstytucja RP, Zasady ogólne, Wolności, prawa i obowiązki człowieka i obywatela, art. 30) podkreśla przyrodzoną i niezbywalną godność człowieka, co stanowi źródło wolności i praw każdego człowieka i obywatela. Owa godność - wymieniana także w każdym innym dokumencie regulującym obecność człowieka w życiu społecznym jest w myśl Konstytucji nienaruszalna, a jej poszanowanie i ochrona jest obowiązkiem władz publicznych. Artykuł 31 Konstytucji podkreśla także, że każdy jest obowiązany szanować wolności i prawa innych oraz nietykalność osobistą. Nikogo nie wolno zmuszać do czynienia tego, czego prawo mu nie nakazuje. Jest to szczególnie istotny zapis w odniesieniu do pracy pracownika socjalnego, bowiem jedną z ważniejszych zasad w pracy socjalnej jest zasada samostanowienia. Zasada ta jest także wskazana w art. 47 Konstytucji. Jednocześnie podkreślona jest równość wobec prawa wszystkich obywateli, co jednocześnie oznacza zakaz dys- 
kryminowania ze względu na jakąkolwiek cechę osobową (w tym wiek i sprawność). Obywatelskie prawo do zabezpieczenia społecznego w razie niezdolności do pracy ze względu na chorobę lub inwalidztwo oraz po osiągnięciu wieku emerytalnego zapewniają zapisy art. 67. Natomiast art. 68 wskazuje, że każdy człowiek ma zapewniony dostęp do świadczeń opieki zdrowotnej finansowanej ze środków publicznych. W sposób jednoznaczny, oddzielnym zapisem (Konstytucja RP, art. 69) potwierdzone są prawa osób z niepełnosprawnością, w którym Państwo zobowiązuje się do udzielenia pomocy w zabezpieczaniu egzystencji, przysposobieniu do pracy oraz komunikacji społecznej.

\section{Karta Praw Człowieka (Universal Declaration of Human Rights)}

Trzecia Sesja Ogólnego Zgromadzenia ONZ, obradująca w Paryżu, uchwaliła 10 grudnia 1948 r. Powszechną Deklarację Praw Człowieka. Dokument ten stanowi niewątpliwie jedno z największych i najtrwalszych osiągnięć ONZ. Przetłumaczona na większość języków świata Powszechna Deklaracja Praw Człowieka zbiera oraz porządkuje osiągnięcia i postulaty człowieka, który od wielu setek lat toczy nieskończoną jeszcze walkę o swoją wolność i godność. W odniesieniu do poruszanej $\mathrm{w}$ artykule problematyki warto zacytować zapis art. 12 Karty, który podkreśla, że „nie wolno ingerować samowolnie w czyjekolwiek życie prywatne, rodzinne, domowe, ani w jego korespondencję, ani też uwłaczać jego honorowi lub dobremu imieniu. Każdy czlowiek ma prawo do ochrony prawnej przeciwko takiej ingerencji lub uwłaczaniu" (Tekst Karty Praw Człowieka, http://www.unesco.pl/fileadmin/user_upload/pdf/Powszechna_Deklaracja_Praw_Czlowieka.pdf, dostęp: 20.10.2015).

\section{Europejska Konwencja o Ochronie Praw Człowieka (The European Convention for the Protection of Human Rights and Fundamental Freedoms)}

Konwencja o Ochronie Praw Człowieka i Podstawowych Wolności ${ }^{1}$ sporządzona w Rzymie dnia 4 listopada 1950 r., weszła w życie 3 września 1953 r. Dotychczas uzupełniana kilkoma protokołami, obowiązuje wszystkie kraje będące członkami Unii Europejskiej. Tekst Konwencji w wielu miejscach podkreśla niezbywalne prawa człowieka. Poza wartościami odnoszącymi się do poszanowania życia (art. 9) i prawa do wchodzenia w związek małżeński (art. 12) zapisy Konwencji bardzo wyraźnie podkreślają, że korzystanie w wymienionych w Konwencji z praw i obowiązków powinny być realizowane bez jakichkolwiek form dyskryminacji (art. 14) (także bez względu na płeć, wiek czy niepełnosprawność).

1 Pełny tekst Konwencji na stronie http://isap.sejm.gov.pl/DetailsServlet?id=WDU19930610284 [dostęp: 3.10.2015] 


\section{Europejska Karta Społeczna (The European Social Charter)}

Europejski Komitet Praw Społecznych (ECSR) jest organem odpowiedzialnym za monitorowanie przestrzegania postanowień Europejskiej Karty Społecznej². Europejska Karta Społeczna jest konwencją Rady Europy, która zawiera katalog praw człowieka o charakterze społecznym i ekonomicznym. Karta została przyjęta w 1961 r. W 1991 r. przyjęto Protokół Zmieniający Europejską Kartę Społeczną, a w 1996 r. - Zrewidowaną Europejską Kartę Społeczną.

Europejska Karta Społeczna zajmuje szczególne miejsce w dorobku normatywnym Rady Europy - wraz z Europejską Konwencją o Ochronie Praw Człowieka z $1950 \mathrm{r}$. Tworzy podstawowe ramy europejskiego systemu ochrony praw człowieka, uzupełniając zawarte w Konwencji prawa polityczne i obywatelskie o katalog praw społecznych.

Europejska Karta Społeczna definiuje cele polityki społecznej oraz chroni zasadnicze prawa społeczne i ekonomiczne. Karta ustanawia i stosunkowo dokładnie określa zobowiązania państw w sferze szeroko rozumianej polityki społecznej. Pełne zatrudnienie, bezpieczeństwo pracy dzięki wysokiemu poziomowi ochrony praw pracowniczych, wysoki poziom ochrony socjalnej, spójność społeczna, to cele, do realizacji których zobowiązuje Karta. Poza wskazaniem na najważniejsze prawa człowieka, czyli poszanowanie godności osobistej, poszanowanie życia prywatnego i rodzinnego, Konwencja wyraźnie podkreśla zakaz dyskryminacji ze względu na różne atrybuty człowieka, w tym niepełnosprawność i wiek. Dwa artykuły w sposób bezpośredni odnoszą się do omawianej grupy osób. Artykuł 25 wskazuje na prawa osób w podeszłym wieku. Zapis artykułu podaje, że Unia Europejska uznaje i szanuje prawo osób w podeszłym wieku do godnego i niezależnego życia oraz do uczestniczenia w życiu społecznym i kulturalnym.

Natomiast art. 26 Karty zawiera zapis co do integracji osób z niepełnosprawnością i wskazuje, że Unia Europejska uznaje i szanuje prawo osób niepełnosprawnych do korzystania ze środków mających zapewnić im samodzielność, integrację społeczną i zawodową oraz udział w życiu społeczności i uznaje (art. 15) prawo osób niepełnosprawnych fizycznie lub umysłowo do szkolenia zawodowego, rehabilitacji oraz readaptacji zawodowej i społecznej $W$ celu zapewnienia skutecznego wykonywania prawa osób niepełnosprawnych fizycznie lub umysłowo do szkolenia zawodowego, rehabilitacji oraz readaptacji zawodowej i społecznej strony ratyfikujące tekst Karty zobowiązują się do podjęcia koniecznych środków w celu zapewnienia osobom niepełnosprawnym ułatwień szkoleniowych, w tym - jeżeli to konieczne - utworzenie wyspecjalizowanych instytucji publicznych lub prywatnych; podjęcie odpowiednich środków w celu zatrudnia-

2 Pełny tekst Europejskiej Karty Społecznej, wraz z Zrewidowanym Tekstem na stronie: http://www .strasburgre.msz.gov.pl/pl/o_re/monitoring/eks/ [dostęp: 01.10.2015]. 
nia osób niepełnosprawnych, takich jak wyspecjalizowane służby pośrednictwa pracy, ułatwiania podejmowania pracy chronionej oraz środki dla zachęcania pracodawców do zatrudniania osób niepełnosprawnych.

\section{Konwencja Praw Osób Niepełnosprawnych}

Konwencja Praw Osób Niepełnosprawnych ${ }^{3}$ przyjęta została przez Zgromadzenie Ogólne Narodów Zjednoczonych 13 grudnia 2006 r., podpisana przez Polskę 20 marca 2007 r., a ratyfikowana w dniu 6 września 2012 r. Celem Konwencji jest ochrona i zapewnienie pełnego i równego korzystania z praw człowieka oraz podstawowych wolności przez osoby z niepełnosprawnością na równi ze wszystkimi innymi obywatelami. Kraje, które ratyfikowały tekst Konwencji, zobowiązały się do wprowadzenia w życie zawartych w Konwencji standardów postępowania w celu zapewnienia osobom z niepełnosprawnością realizacji tych praw.

Tekst Konwencji jest najszerszym dokumentem odnoszącym się do praw i wolności osób z niepełnosprawnością; podejmuje i reguluje funkcjonowanie osób z niepełnosprawnością na wielorakim polu aktywności. Poza wartościami odnoszącymi się praw poszanowania godności, niedyskryminacji i równości, pełnego udziału w życiu społecznym, równości szans i dostępności oraz poszanowania praw do zachowania tożsamości (art. 1 i 5) tekst Konwencji w wyraźny sposób podkreśla prawo do wolności i bezpieczeństwa osobistego (art. 14), oznacza to, że osoby z niepełnosprawnością nie będą pozbawiane wolności bezprawnie i samowolnie. Artykuł 16 nadaje prawo osobom z niepełnosprawnością do wolności od wykorzystywania, przemocy i nadużyć. Jest to zapis szczególnie skierowany do rodzin, opiekunów i jednostek wsparcia oraz pomocy. Nie oznacza on tylko zakazów nadużyć we wspomnianym aspekcie, ale nadaje także obowiązek do zapewnienia informacji i edukacji na temat unikania, rozpoznawania i zgłaszania przypadków wykorzystywania, przemocy oraz nadużyć. Kolejne zapisy podkreślają ochronę integralności osobistej (art. 17) i poszanowania prywatności (art. 22). Zapis art. 22 podkreślą, że osoba z niepełnosprawnością, niezależnie od miejsca zamieszkania lub warunków życiowych, nie może być narażona na „arbitralną lub bezprawną ingerencję $\mathrm{w}$ życie prywatne, życie rodzinne, dom lub korespondencję (...), ani też na bezprawne naruszenie jej czci i reputacji.(...)". Warto również wspomnieć o zapisie wynikającym z art. 23 Konwencji, który nadaje osobom z niepełnosprawnością prawo do niedyskryminacji we "(...) wszystkich sprawach dotyczących macierzyństwa, rodziny, rodzicielstwa i związków na zasadzie równości z innymi osobami". Zapis ten nadaje osobom z niepełnosprawnością prawo do zawarcia małżeństwa, zachowania zdolności rozrodczych oraz decydowania

3 Pełny tekst Konwencji ONZ Praw Osób Niepełnosprawnych na stronie https://www.rpo.gov.pl/ pl/konwencja-o-prawach-osob-niepelnosprawnych [dostęp: 21.10.2015]. 
o liczbie i czasie urodzenia dzieci, o ile dzieje się na podstawie swobodnie wyrażonej i pełnej zgody przyszłych małżonków.

\section{Kodeks Etyczny Pracownika Socjalnego}

Tekstem, który w sposób bezpośredni odnosi się do zasad etycznych w pracy socjalnej, poza wspomnianymi powyżej dokumentami, jest Kodeks Etyczny Pracownika Socjalnego. Kodeks Etyczny Polskiego Towarzystwa Pracowników Socjalnych jest kodeksem etyki zawodowej i stanowi zbiór zasad postępowania zawodowego pracowników socjalnych w Polsce. Twórcą kodeksu etycznego na gruncie polskim jest Polskie Towarzystwo Pracowników Socjalnych.

Potrzeba stworzenia Kodeksu Etycznego wynika ze świadomości, iż praca socjalna jest siłą napędową zmian społecznych. Kodeks Etyczny, jako zbiór wytycznych codziennego postępowania zawodowego ma służyć wszystkim tym, którzy zdecydowali się związać swą przyszłość z zawodem pracownika socjalnego. Zawiera standardy zachowań etycznych, których pracownicy socjalni muszą przestrzegać, wykonując swój zawód. Standardy te odnoszą się do zawodu, relacji ze współpracownikami, klientami, pracodawcą i społeczeństwem.

Jednak Kodeks Etyczny to nie tylko zbiór nakazów i zakazów, których należy przestrzegać, wykonując zawód pracownika socjalnego, lecz jest również przekazaniem pewnych wartości, m.in. takich jak:

- działania na rzecz dobrobytu społecznego,

- poprawa warunków bytu osób, rodzin, grup,

- działania, zaangażowanie na rzecz sprawiedliwości społecznej.

Kodeks nawiązuje do idei pracy socjalnej - poszanowania godności człowieka i obrony tej godności, prawa człowieka do samostanowienia, dbałości o równość szans. Kodeks jest zapisem odnoszącym się do czterech wymiarów odpowiedzialności pracownika socjalnego: odpowiedzialności wobec klienta, przełożonego, współpracowników oraz wobec społeczeństwa. Dział II Kodeksu odnosi się do odpowiedzialności etycznej pracownika socjalnego wobec klienta jest podstawowym punktem odniesienia do praw i obowiązków w zakresie pracy z klientem. Poniże zapisy określają owe prawa i obowiązki:

1. „Pracownik socjalny zobowiązany jest do poszanowania godności klienta i jego prawa do samostanowienia.

2. Pracownik socjalny jest zobowiązany do równego traktowania klientów bez względu na wiek, płeć, stan cywilny, orientację seksualną, narodowość, wyznanie przekonania polityczne, stan zdrowia, rasę, kolor skóry oraz inne preferencje i cechy osobiste.

3. Pracownik socjalny powinien uznać zasadę spolegliwej opiekuńczości za podstawową regułę określającą kontakty z klientem. 
4. Pracownik socjalny zobowiązany jest wykazać zaangażowanie na rzecz pomocy klientowi w rozwiązywaniu jego trudności życiowych oraz wykorzystać w tym celu swoją wiedzę, umiejętności zawodowe i kompetencje.

5. Pracownik socjalny powinien - stosownie do możliwości klienta - wzmacniać jego wysiłki na rzecz życiowego usamodzielnienia.

6. Pracownik socjalny zobowiązany jest do udzielenie klientowi pełnej informacji na temat dostępnych świadczeń.

7. Pracownik socjalny powinien udzielić klientowi precyzyjnej informacji na temat uprawnień do świadczeń i wynikających stąd zobowiązań.

8. Pracownik socjalny winien zasięgnąć konsultacji współpracowników i zwierzchników w przypadku, gdy leży to w żywotnym interesie klienta.

9. Pracownik socjalny za zgodą klienta ma prawo zaprzestać świadczenia pomocy, gdy wyczerpane zostały przewidziane prawem świadczenia lub gdy takie świadczenia nie są już potrzebne.

10. Pracownik socjalny ma prawo do zmiany formy udzielanej pomocy $w$ przypadku stwierdzenia wykorzystania świadczeń niezgodnie z przeznaczeniem.

11. Pracownik socjalny zobowiązany jest do zachowania w tajemnicy informacji uzyskanych od klienta w toku czynności zawodowych.

12. Pracownik socjalny ma prawo bez zgody klienta przekazywać poufne informacje wyłącznie wówczas, gdy przemawiają za tym ważne względy zawodowe".

Kodeks nawiązuje do idei pracy socjalnej - poszanowania godności człowieka i obrony tej godności, prawa człowieka do samostanowienia, dbałości o równość szans. Zawiera standardy zachowań etycznych, których pracownicy socjalni powinni przestrzegać, wykonując swój zawód. Stanowi także podstawę do rozwiązywania sporów etycznych. Kodeks obejmuje etyczne regulacje możliwie najistotniejszych sfer aktywności pracownika socjalnego. Ustanawiając etyczne standardy wykonywania zawodu, należy mieć jednocześnie świadomość, iż treści zawarte w Kodeksie nie są ostateczne i mogą ulegać zmianom wraz z rozwojem zawodu i świadomości społecznej.

\section{Realizacja zasad etycznych $\mathrm{w}$ pracy $\mathrm{z}$ osobami starszymi} i z niepełnosprawnością. Wybrane zasady. Wyzwania i trudności

Praca socjalna jako profesja pomocowa opiera się na relacji pomagania. Ten specyficzny rodzaj relacji pomiędzy pracownikiem socjalnym a klientem stanowi podstawę podejmowania konstruktywnych działań pomocowych. Jak zauważa Carl Rogers, skuteczność relacji pomagania zależna jest od cech pomagającego, takich jak: bezwarunkowa akceptacja klienta, spójność, empatia oraz autentyczność 
(Rogers 1991, s. 34-36). C. Combs natomiast wskazuje, iż najważniejszymi cechami osób pomagających są: prezentowe postawy wobec siebie i innych, obraz własnej osoby oraz podejście do pomagania (Okun 2002, s. 39). Istotne znaczenie dla rozwoju relacji pomiędzy pracownikiem socjalnym a klientem ma prawidłowa komunikacja i feedback zarówno ten pozytywny, jak i negatywny (Pikuła 2013, s. 139-151). Niemniej jednak, niezależnie od kryteriów jakie byśmy przyjęli do scharakteryzowania relacji pomagania, należy pamiętać, iż profesje pomocowe, w tym również praca socjalna, muszą opierać się na przestrzeganiu norm i wartości etycznych. Realizacja tych zasad pozwala na stworzenie optymalnych warunków do zawiązywania się relacji pomagania. Do kanonu podstawowych zasad etycznych pracy socjalnej zalicza się:

Godność. Poszanowanie godności osoby ludzkiej jest najważniejszą zasadą jaka powinna być przestrzegana przez pracowników socjalnych. Niezbywalność godności ludzkiej wyraża się w pragnieniu traktowania z szacunkiem z poszanowaniem wszelkich praw. Poprzez poszanowanie godności i szacunek wobec klienta pracownik socjalny zyskuje zaufanie oraz nawiązuje relacje pomagania. Niedopuszczalne jest by klient był traktowany w sposób przedmiotowy, wskazujący niejako na jego „zależność” od pracownika socjalnego czy też pomocy społecznej. Praca socjalna z osobą starszą i niepełnosprawną wymaga szczególnej troski, cierpliwości i zrozumienia dla podopiecznego. Z racji ubytków psychofizyczno-somatycznych, często kontakt $\mathrm{z}$ takimi jednostkami jest utrudniony, postępy mogą być niewidoczne, co dodatkowo będzie wpływało na odczuwanie frustracji i niezadowolenia przez pomagającego. Poszanowanie godności osób starszych i niepełnosprawnych winno przejawiać się w życzliwym podejściu. Pracownik socjalny powinien pamiętać, iż starość jako ostatnia faz życiowa, może przebiegać w sposób patologiczny ${ }^{4}$, dlatego tak ważne staje się tworzenie poczucia bezpieczeństwa, akceptacji, wzmacniania i zrozumienia seniora.

Akceptacja. Zasada akceptacji w pracy socjalnej wynika z niezbywalnego prawa człowieka do godności i szacunku. Indywidualizacja jednostki jej losów i przeżyć stanowi podstawę prawidłowej pełnej diagnozy oraz tworzenia planu wsparcia i pomocy. „Akceptacja w relacji zawodowej objawia się $\mathrm{w}$ formie szczerego zainteresowania, uważnego słuchania, intencjonalnego reagowania uznającego punkt widzenia drugiej osoby oraz tworzenia klimatu wzajemnego zaufania" (DuBois, Miley 1996, s. 122). Postawa akceptacji wynika z prawidłowo rozumianej empatii, która jest istotna $\mathrm{w}$ profesjach ukierunkowanych na pomoc drugiemu.

4 Proces starzenia się może przebiegać w sposób: pomyślny (terminu tego używa się w odniesieniu do seniorów, którzy żyją znacznie dłużej, niż pozostali przedstawiciele tej grupy oraz doświadczają wysokiej jakości życia), naturalny (charakterystyczny dla danej populacji), patologiczny (na naturalne zmiany starsze nakładają się jednostki chorobowe znacznie obniżające jakość życia osób starszych) - temat rodzajów starzenia się w: Fizjologiczne starzenie się. Profilaktyka i rehabilitacja, red. A. Marchewka, Z. Dąbrowski, J. A. Żołądź, Wydawnictwo PWN, Warszawa 2012. 
W kontekście akceptacji ważną cechę stanowi cierpliwość oraz umiejętne słuchanie. Grupę czynników utrudniających prawidłową akceptację możemy podzielić na dwie płaszczyzny:

a) czynniki wewnętrzne - te które tkwią w pracowniku socjalnym; zaliczamy do nich: poziom empatii, posiadaną wiedzę, uprzedzenia, stereotypowe postrzeganie, ocenianie;

b) czynniki zewnętrze - tkwiące w kliencie: brak samoakceptacji, nieufność, zniekształcony obraz samego siebie, postawa izolacji, obwinianie siebie lub świata, zależności (DuBois, Miley 1996, s. 122).

Wyzwaniem a zarazem trudnością dla pracownika socjalnego może stanowić brak samoakceptacji klienta. Nieumiejętne przystosowanie się do starości, brak pozytywnej wizji przyszłości, nawarstwiające się choroby mogą implikować u seniora poczucie beznadziejności, zaniechanie samooceny i spadek własnej wartości. „Nauczenie samoakceptacji”, ukazanie pozytywów oraz zalet klienta czy odbudowa wartościowego wizerunku pozwalają na polepszenie jakości życia seniora. Często brak samoakceptacji starszego klienta wynika z niekorzystnego bilansu minionych lat, co dodatkowo znacznie obniża poziom odczuwanej satysfakcji życiowej. Przeszkodą w pracy z osobą starszą stanowi również rodzaj jej niepełnosprawności. Adekwatność działań wspierających, pomocowych, aktywizujących sprzyja prawidłowym zmianom w funkcjonowaniu chorego. Brak wiedzy na temat schorzeń klienta stanowi przeszkodę dla pracownika, który sam we własnym zakresie powinien poszerzyć informację na temat danej jednostki chorobowej.

Akceptacja klienta z niepełnosprawnością, schorowanego, z postępującym procesem straszenia, nie jest łatwa. Jednostki te stanowią pewnego rodzaju specyficzną grupę klientów. Brak perspektyw na przyszłość czy świadomość zbliżającej się śmierci generują postawę obojętności i zniechęcenia („wszystko mi jedno”). Pracownik socjalny, który podejmuje się współpracy z seniorami, może doświadczać zniechęcenia oraz frustracji, a tym samym mieć problem z akceptacją klienta, który sam siebie nie akceptuje.

Prawo do samostanowienia. Niezależnie od schorzeń, wieku, płci każdy klient korzystający z pomocy społecznej ma prawo do samostanowienia. Pracownik socjalny nie ma prawa czegoś „narzucać lub nakazywać”, wszelkie podjęte działania muszą być zaakceptowane przez osobę potrzebującą. Dobrowolność jest podstawą samostanowienia; możliwość wyboru, wypowiedzenie swojego zdania, komunikowanie swoich potrzeb wyznaczają stopień i zakres samostanowienia klienta. Prawo do samostanowienia obejmuje również "dopomożenie klientom w perspektywicznym spojrzeniu na trapiące ich problemy, przed którymi stoją, zapewnienie informacji o możliwościach zdobycia środków oraz 
działanie na zasadzie partnerstwa z klientem z zamiarem osiągnięcia wspólnie określonych celów" (DuBois, Miley 1996, s. 128).

$\mathrm{W}$ pracy z osobą starszą i niepełnosprawną pojawia się niebezpieczeństwo przedmiotowego traktowania klienta. Wiek i schorzenia mogą wpływać na gorszą komunikację. Zbyt duża liczba klientów prowadzonych przez pracownika socjalnego może wywoływać "presję czasu”, która będzie skutkowała nieaktywnym słuchaniem seniora, a tym samym niedostrzegania potrzeb osób starszych i niepełnosprawnych.

Poufność. Zasada poufności związana jest z prawem każdego człowieka do prywatności, niezależnie od uwarunkowań i czynników zewnętrznych. Oznacza to, że klient musi wyrazić zgodę na to, aby jego dane lub informacje zdobyte $\mathrm{w}$ toku postępowania pomocowego zostały ujawnione osobom trzecim. Przestrzeganie zasady poufności pozwala na tworzeniu pozytywnej atmosfery sprzyjającej zaufaniu, a tym samym konstruktywnej relacji pomagania. „Nakazy, które stwarza konieczność zachowania poufności, dotyczą również prowadzenia kartotek danych. Informacje chronić można jedynie do pewnej granicy, w zależności od polityki danej instytucji oraz prawodawstwa obowiązującego (...). Najbardziej kuszą do naruszenia poufności sytuacje prowokujące do wybuchu gniewu (DuBois, Miley 1996, s. 130).

Pomimo przestrzegania zasad, $\mathrm{w}$ profesji pracownika socjalnego nieuniknione stają się dylematy etyczne. Źródeł tychże dylematów należy upatrywać zarówno w samym pracowniku socjalnym, jak i w organizacji danej instytucji. Literatura przedmiotu wskazuje, iż kwestie problemowe związane z dylematami etycznymi można rozpatrywać $w$ trzech aspektach:

a) konfliktach sprzecznych interesów - konflikty te mogą występować zarówno pomiędzy pracownikiem socjalnym a klientem, grupami klientów, klientami a resztą populacji, instytucją a klientami;

b) dwoistości ról pracownika socjalnego, który zarówno pomaga i kontroluje;

c) konfliktach pracownika wynikających z zobowiązania do dbania o dobro klienta i instytucji (Olech 2013, s. 18-19).

F. Reamer, wskazując na typologię dylematów w pracy socjalnej, zauważa, iż pracownik socjalny może doświadczać konfliktów związanych z:

a) bezpośrednią obsługą jednostek i rodzin,

b) planowaniem i wdrażaniem polityki i programów pomocy społecznej,

c) stosunkami pomiędzy przedstawicielami własnej profesji (za Olech 2013, s. 24).

Według autora dylematy pierwszej kategorii (najistotniejsze) zachodzą w wymiarze obsługi jednostki i rodziny. Mogą pojawić się tutaj problemy związane z zachowaniem zasady poufności, prawdomówności, świadomej zgody klienta na interwencję, konflikt $\mathrm{w}$ zachowaniu pracownika socjalnego pomiędzy zobowiązaniami wobec pracodawcy a zobowiązaniami wobec klienta. 
Przestrzeganie zasad etycznych w pracy socjalnej, niezależnie od grupy klientów, stanowi wyzwanie dla pracowników, którym zawsze towarzyszyć będą dylematy i konflikty. Profesja ta posiada znaczne obciążenie emocjonalne, kumulacja emocji zarówno tych negatywnych, jak i pozytywnych może wpływać na podejmowane decyzje. Obciążenie pracą biurową oraz nawarstwiające się problemy klientów nie pozostają bez wpływu na funkcjonowanie pracownika socjalnego, pomimo wysokiego poziomu empatii, jaki może prezentować.

\section{Konkluzje i rekomendacje}

W swojej codziennej pracy pracownicy socjalni doświadczają dylematów etycznych związanych z bezpośrednią praktyką, dotyczą one takich zagadnień, jak: niepewność co do słuszności dokonywanych wyborów, konieczność wybierania pomiędzy działaniem skutecznym a działaniem zgodnym z przepisami oraz podejmowaniem działań wbrew woli klienta zarówno w kontekście samego świadczenia usług, jak i sposobu ich finalizowania. Równie często pojawiają się jednak trudności związane z dystrybucją ograniczonych zasobów finansowych, prawem do pomocy. Są one dodatkowo potęgowane przekonaniami o niesprawiedliwości społecznej (Reamer ${ }^{1994)}$. Podstawowe wartości, jakie pracownicy socjalni uznają za najważniejsze w swojej pracy, to: odpowiedzialność, godność drugiej osoby, uczciwość wobec innych i samego siebie, rzetelność, a także tolerancja i sprawiedliwość (Bieńko 2012). Temat odpowiedzialności w pracy socjalnej warto omówić szerzej. Roman Ingarden rozróżnia cztery sytuacje, w których występuje fenomen odpowiedzialności:

- ktoś jest za coś odpowiedzialny,

- ktoś podejmuje odpowiedzialność za coś,

- ktoś jest za coś pociągany do odpowiedzialności,

- ktoś działa odpowiedzialnie (Ingarden 1987, s. 73-74).

Pracownicy socjalni czują się odpowiedzialni wobec klienta, za działanie (tak i czyn, jak i jego skutek). Znawcy tematu uznają, że przekonania te są zgodne z maksymalistycznym pojmowaniem odpowiedzialności Emmanuela Levinasa, zdaniem którego „odpowiedzialność jest podstawą każdego spotkania dwóch osób, w każdej relacji i więzi pomiędzy nimi”. „Odpowiedzialność jest od początku »odpowiedzialnością « za drugiego. Oznacza to, że jestem odpowiedzialny za jego odpowiedzialność" (Lewinas 1991, s. 55). Odpowiedzialność nie może jednak pozbawiać drugiej strony relacji jej praw i obowiązków oraz odpowiadania za samą siebie. W tym kontekście warto zastanowić się nad pojęciem odpowiedzialności pracownika socjalnego $\mathrm{w}$ relacji $\mathrm{z}$ klientem, którego prawo do samostanowienia 
jest ostatnio mocno podkreślane. Prawo to daje mu nie tylko możliwość podejmowania własnych decyzji i dokonywania autonomicznych wyborów, ale również prawo do ponoszenia ich konsekwencji. Jest to wątek szczególnie ważny i trudny $\mathrm{w}$ kontekście pracy z osobami $\mathrm{w}$ różnego rodzaju kryzysach bądź niepełnosprawnymi, $w$ tym osobami upośledzonymi intelektualnie i z zaburzeniami psychicznymi czy osobami starczymi doświadczającymi wielorakich konsekwencji swojego wieku. Zawód pracownika socjalnego niesie ze sobą konflikty interesów, opinii, perspektyw i pozycji w obszarze świadczenia usług. Odpowiedzialność pracowników socjalnych rozpatrywać należy również w kontekście zobowiązań wobec pracodawcy (zatrudniającej go instytucji), relacji ze współpracownikami, z własnym zawodem i wreszcie społeczeństwem. Odpowiedzialność wobec społeczeństwa rozumiana jest zarówno jako propagowanie wiedzy dotyczącej działalności ośrodków pomocy społecznej, pracowników socjalnych oraz dostępności świadczonych usług. Jej celem jest wypracowanie wizerunku instytucji i zawodu.

Drugi kierunek działań dotyczy badania problemów społecznych, ich identyfikowania, informowania o nich społeczeństwa i zapobiegania im. Kolejny mocno eksponowany w badaniach naukowych obszar odpowiedzialności pracowników socjalnych dotyczy środków finansowych, które społeczeństwo przeznacza na pomoc społeczną, a którymi dysponują pracownicy socjalni. Są oni zobowiązani do zgłaszania swoim przełożonym informacje na temat klientów, którzy marnotrawią środki z pomocy społecznej, wykorzystują je w nieuczciwy sposób. Niektórzy badacze uznają, że łamią oni w ten sposób jedną z zasad zapisanych w kodeksie etycznym, którą jest zachowanie poufności. Wydaje się jednak, że traktowanie zasady poufności na równi z tajemnicą adwokacją lub tajemnicą spowiedzi przez pracowników socjalnych w relacji z klientem, jest poważnym nadużyciem i nie powinno mieć miejsca.

Praca socjalna stanowi profesję ukierunkowaną na pomoc i wsparcie człowiekowi w sytuacji kryzysowej, problemowej. Pracownicy socjalni podejmujący działania z osobami starszymi i niepełnosprawnymi doświadczają różnego rodzaju dylematów, trudności i przeszkód. Przestrzeganie zasad etycznych powinno stanowić dla pracowników socjalnych pewnego rodzaju ułatwienie, drogowskaz, jakie kierunki działań podejmować w celu optymalnej pomocy osobie potrzebującej. Wśród zasad nadrzędną wartość stanowi godność, która w pracy z niepełnosprawnymi seniorami nabiera szczególnego znaczenia. Godna starość to dla wielu osób starszych wyznacznik satysfakcji życiowej, pracownicy socjalni przez swoje działania mogą przyczynić się do przeżywania przez swoich klientów starości z należytym szacunkiem, $\mathrm{w}$ atmosferze zrozumienia i empatii. 


\section{Bibliografia}

Bieńko M. (2012), Dylematy profesji i roli w refleksyjnym projekcie tożsamości wspótczesnego pracownika [w:] Pracownicy socjalni i praca socjalna w Polsce Między stużba społeczną a urzędem, red. M. Rymsza, Instytut Spraw Społecznych, Warszawa.

Crimmins E. (2004), Trend in the health of the elderly, "Annual Review of Public Health", vol. 25.

DuBois B., Miley K.K. (1996), Biblioteka Pracownika Socjalnego, Warszawa.

Europejska Karta Społeczna, http://www.strasburgre.msz.gov.pl/pl/o_re/monitoring/eks/, [dostęp: 1.10.2015].

Fizjologia starzenia się. Profilaktyka i rehabilitacja (2012), red. A. Marchewka, Z. Dąbrowski, J. A. Źołądź, Wydawnictwo PWN, Warszawa.

Hahn H. (1994), The minority group model of disability: Implications for medical sociology, „Research in Sociology of Health Care", vol. 11.

Ingarden R. (1987), Książeczka o człowieku, Wydawnictwo Literackie, Kraków.

Kelly M.P., Locker D. (1996), Medical sociology, chronic illness and the body , „Sociology of Health \& Illness", vol. 18, issue 2.

Karta Praw Człowieka, http://www.unesco.pl/fileadmin/user_upload/pdf/Powszechna_ Deklaracja_Praw_Czlowieka.pdf [dostęp: 20.10.2015].

Kirenko J. (2006), Pojęcie i zakres niepetnosprawności [w:] Niepetnosprawność. Wybrane aspekty sytuacji osób niepetnosprawnych i ich rodzin, red. W. Janocha, Wydawnictwo Jedność, Kielce.

Kirenko J. (2007), Indywidualna i społeczna percepcja niepetnosprawności, Wydawnictwo UMCS, Lublin.

Konstytucja Rzeczpospolitej Polskiej z dnia 2 kwietnia 1997.

Konwencja ONZ Praw Osób Niepełnosprawnych, https://www.rpo.gov.pl/pl/konwencjao-prawach-osob-niepelnosprawnych [dostęp: 21.10.2015].

Konwencja o Ochronie Praw Człowieka i Podstawowych Wolności, http://isap.sejm. gov.pl/DetailsServlet?id=WDU19930610284 [dostęp: 03.10.2015].

Kunkel R.S., Brown J.S., Whittington F.J. (2014), Global Aging. Comparative Perspective on Aging and a Life Course, Springer Publishing Company, New York.

Lewinas E. (1991), Etyka i nieskończony. Rozmowy z Philipp'em Nemo, Wydawnictwo Naukowe Papieskiej Akademii Teologicznej, Kraków.

Majewski T. (1995), Rehabilitacja zawodowa osób niepetnosprawnych, CB-RRON, Warszawa.

Międzynarodowa Klasyfikacji Funkcjonowania, Niepełnosprawności i Zdrowia, http:// apps.who.int/iris/bitstream/10665/42407/67/9241545429_pol.pdf?ua=1 [dostęp: 23.07.2015].

Okun B. (2002), Skuteczna pomoc psychologiczna, Instytut Psychologii Zdrowia, Warszawa.

Olech A. (2013), Źródła i rodzaje dylematów etycznych w pracy socjalnej oraz możliwości ich rozwiązywania [w:] Dylematy etyczne pracowników socjalnych, red. M. Sokołowska, Centrum Rozwoju Zasobów Ludzkich, Warszawa.

Pikuła N. (2013), Feedback w pracy socjalnej, „Labor et Educatio”, no. 1.

Putnam M. (2006), Aging and Disability: Crossing Network Lines, Springer Publishing Company, New York.

Reamer F. (1994), Dylematy etyczne w praktyce pracy socjalnej [w:] Wypisy z wybranych zagadnień pracy socjalnej, red. M. Bocheńska-Seweryn, K. Frysztacki, K. Kluzowa, Uniwersytet Jagielloński, Instytut Socjologii, Kraków. 
Rogers C. (1991), Terapia nastawiona na klienta. Grupy spotkaniowe, Thesaurus Press, Wrocław. Torres-Gil F., Putnam M. (2004), The politics of aging with disability: Health care policy and the shaping of a public agenda [w:] Aging with disability, red. B. Kemp, L. Mosqueda, J. Hopkins University Press, Baltimore.

Ustawa z dnia 12 marca 2004 roku o pomocy społecznej (tekst jedn.: Dz. U. z 2009 r. Nr 175, poz. 1362, z późn. zm.).

Ustawa z dnia 16 lutego 2007 r. o zmianie ustawy o pomocy społecznej (Dz. U. Nr 48, poz. 320).

Woźniak Z. (2007), Teoretyczne podstawy badań nad aktywnościq zawodowa osób z ograniczona sprawnościa [w:] Osoby z ograniczonq sprawnościq na rynku pracy, red. A. Brzezińska, Z. Woźniak K. Maj, Wydawnictwo Academica, Warszawa. 